\title{
PENGUNAAN BAHASA TERNATE DALAM SASTRA LISAN DAN ACARA RITUAL KEAGAMAAN
}

\author{
Kodrat Hi Karim ${ }^{1}$ dan Rustam Hasim ${ }^{2}$ \\ ${ }^{1,2}$ Pengajar Program Studi PGSD Universitas Khairun Ternate \\ kodrahkarim@gmail.com \\ rustamhasyim@gmail.com
}

\begin{abstract}
This paper describes types of phrases expressed in Ternate oral literature. As various types of Indonesian literature, it is also found that oral literature of Ternate consists of many different forms and type, this variety can be classified into different classification such as based on the period of before and after the establishment of Islamic teaching in this area. Ternate oral literature has a close relationship with the tradition of its society such as its ethics, social and economic life both internally and externally. Oral tradition in the sultanate of Ternate is a set of habits and behaviors of daily life inherited from generation to generation. Before the introduction of Islam which is known as the period ofmomoleperiod, this country already has a number of oral traditions that includes cultural values, customs, community systems and belief systems.In line with the development of Ternate language into lingua-france in North Maluku, Ternate literature then became the property of the community as North Maluku. Even it expands spreading alongside the development of the power of the Sultanate of Ternate from XV to XVII century. It is no wonder that if the oral literature is influenced by local languages as well as Malay, Arabic and Javanese languages.
\end{abstract}

Keywords: Ternate Language, Oral Literature, Religious Rituals and Ternate Island.

\section{Pengantar}

Bahasa Ternate merupakan bahasa induk dari berbagai bahasa daerah di Maluku Utara.Bahasa Ternate termasuk dalam kelompok bahasa TernateHalmahera.Artinya serumpun dengan berbagai bahasa daerah yang meliputi pulau Ternate dengan pulau Halmahera. Wilayah Maluku Utara merupakan suatu wilayah kebahasaan yang memeliki ciriciri yang khas yang tidak terdapat di wilayah lain di Nusantara. Bahakan penyebarannya berpengaruh sampai di pulau Mindano, kepulauan Sulu, Sabah di Kalimantan Utara, Sulawesi Utara, sepanjang pantai Sulawesi Tengah-Selatan, pulau Banggai, kepulauan Sula, pulau Waigo, pulau Morotai. Dengan demikian tidak mengherangkan kalau sejumlah ahli lingustik pernah mengadakan pendalam atas struktur kebahasaan di wilayah ini.

Sastra lisan Ternate mempunyai kaitan erat dengan tradisi masyarakat yang sangat harmonis dalam tata cara pergaulan, kehidupan sosial ekonomi baik secara intern maupun ekstern. Tradisi lisan di kesultanan Ternate adalah seperangkat kebiasaan dan perilaku kehidupan keseharian yang di wariskan dari generasi ke generasi secara turun temurun di daerah ini. Sejak periode sebelum masuknya agama Islam yang dikenal sebagai periode momole, negeri ini sudah memeliki sejumlah tradisi lisan yang meliputi nilai budaya, adat istiadat, sistem kemasyarakatan dan sistem kepercayaan. Menurut B. Soelarto, bahwa berbagai bahasa daerah di Maluku Utara masih tetap digunakan sebagai bahasa lokal. Ada yang berpendapat bahwa bahasa Ternate termasuk rumpun bahasa Polinesia.Tapi ada juga yang berpendapat bahwa bahasa Ternate termasuk rumpun bahasa Austronesia, berdasarkan kesamaan dalam segi tata bahasa (pronounciation dan vocabulary).

Masyarakat Ternate sejak masa pra Islam telah mempengaruhi olah vokal yang 
167 | JURNAL ILMU BUDAYA

Volume 6, Nomor 1, Juni 2018

bermotifkan religius.Dalam arti bahwa olah vokal itu merupakan bagian dari sarana ritual yang bersifat magis, terutama merupakan matra-matra atau doadoa.Menurut Jusuf Abdulrahman bahwa masuknya agama Islam dan agam Kristen maka terjadilah akulturasi kebudayaan.Sekitar abad ke 14-17 terjadi pula pembauran dengan budaya orangorang Spanyol, Portugis dan Belanda, tetapi dampak pembaurannya tidak sekuat pengaruh agama Islam. Tradisi lisan kesultanan Ternate pada periode tersebut telah banyak di pengaruhi oleh tradisi Islam, namun adat kebiasaan leluhur masih tetap terpelihara dan hidup berdampingan secara terpadu selama keduanya saling membutuhkan dan tidak terjadi benturan. Dalam pelaksanaan upacara-upacara adat tertentu di kawasan Ternate terdapat perpaduan tradisi lisan warisan leluhur dengan tata cara Islam.

Seirama dengan perkembangan bahasa Ternate menjadi lingua-france di Maluku Utara, maka sastra Ternate pun lalu menjadi milik masyarakat se Maluku Utara.Bahkan dalam perkembangannya sampai tersebar ke pulauan Sulu, di Filipina Selatan dan Sabah di Kalimantan Utara (mengikuti perkembangan kekuasaan kesultanan Ternate pada abadabad ke XV sampai awal abad ke XVII).Sehingga tidaklah mengherangkan, apabila sastra lisan sedikit banyak terpengaruh juga oleh bahasa-bahasa lokal serta bahasa-bahasa Melayu, Arab dan Jawa.

Jenis olah vokal yang bersifat magis itu masih di hayati sampai masa kini. Dalam upacara spritisme yang sampai sekarang masih di praktekan secara perseorangan ataupun kelompok-kelompok masyarakat desa, mantra-mantra bersifat magis masih dikumandangkan. Demikian pula doa-doa kepercayaan lama yang sampai sekarang masih di ucapkan oleh sebagian dari warga masyarakat Ternate. Misalnya doa kiye (doa gunung) yang merupakan doa magis kepercayaan lama. Pemujaan gunung, merupakan doa tradisional yang sampai masih kini di parktekan oleh sebagian warga masyarakat.

Dari uraian di atas, tulisan ini akan menjelaskan secara berturut-turut bahasa Ternate dan persebarannya, dan bentukbentuk ungkapan dalam upacara keagamaan yang akan dijelaskan dibawah ini.

\section{A. Bahasa Temate dan Persebarannya}

Bahasa Ternate termasuk dalam kelompok bahasa Ternate Halmahera.Artinya serumpun dengan berbagai bahasa daerah yang meliputi pulau Ternate dengan pulau Halmahera. Adapun bahasa-bahasa dearah yang termasuk kedalam kelompok bahasa Ternate Halamahera, yaitu bahasa-bahasa daerah :

Ternate, Tidore, Ibu, Waioli, Tabaru, Madole, Tobelo, Loda, Galela, Tololiku, Isam.

Antara berbagai daerah terdapat banyak persamaan dalam perbendaharaan kata (vocabulary).Perbedaan antara berbagai bahasa daerah terutama disebebabkan oleh variasi, bentuk dan logat.Sebagai contoh dari persamaan perbendaharaan kata dan perbedaannya dalam variasi, bentuk dan logat kami cantumkan dalam suatu perbandingan antara beberapa kata, (mengenai contoh dari persamaan perbendaharaan kata dan perbedaannya dalam variasi, bentuk dan logat, kami persilahkan untuk melihatnya pada halaman berikut dalam naskah ini).

Lambat laun bahasa Ternate seirama dengan perkembangan kekuasaan Kesultanan Ternate, dapat tumbuh hingga menemukan bentuknya sebagai bahasa pengantar (lingua franca) di kawasan Ternate, Halmahera. Bahkan juga kemudian berkembang lebih luas lagi sampai di wilayah-wilayah yang berada di luar kawasan Maluku Utara.

Bahasa Ternate dalam komunikasinya dengan bahasa-bahasa di luar Maluku Utara dengan sendirinya juga tidak luput dari pengaruh bahasa-bahasa non 
Ternate.Terutama sekali pengaruh dari bahasa Melayu.Banyak kata-kata Melayu yang dijadikan perbendaharaan kata bahasa Ternate.

Setelah Islam masuk, pengaruh bahasa Arab sangat besar.Dan menambah perbendaharaan kata bahasa Ternate. Adapun bahasa-bahasa non Ternate yang sedikit banyak memperkaya perbendaharaan kata-kata bahasa Ternate, ialah bahasa Bare'e (Sulawesi Tengah), bahasa Bugis (Sulawesi Selatan), serta bahasa Jawa. Hal itu erat hubungannya dengan hubungan yang dijalin antara Kesultanan Ternate dengan wilayah Sulawesi yang dahulu pernah menjadi bagian dari wilayah Kesultanan Ternate, sebagai kerajaan vasal atau setidaktidaknya dalam kontex hubungan perdagangan.Sedang dengan bahasa Jawa, terutama karena hubungan persahabatan yang selama berabad-abad terjalin.Dan sebagaimana telah diketahui para Sultan Ternate secara tradisionil belajar ilmu agama Islam di Tuban, Geresik (Jawa Timur).

Kehadiran bangsa Portugis di Ternate sejak awal abad ke XVI rupanya juga memperkaya perbendaharaan kata bahasa Ternate.Bahkan sampai sekarang masih ada tempat-tempat yang penamaannya diambil dari bahasa Portugis.Misalnya desa Kastela, pantai Laguna.

Bahasa Inggris meskipun hanya memerintah singkat di Ternate, juga ikut memberi sedikit sumbangan kata-kata bahasa Inggris ke dalam bahasa Ternate.Dan bahasa Belanda merupakan bahasa asing yang paling lama dikenal, dalam daerah Ternate hanya sedikit menambah perbendaharaan kata.Kata-kata itu khususnya kata-kata atau istilah-istilah yang bersangkut-paut dengan tata pemerintahan.

Kurangnya kata-kata bahasa Belanda yang masuk kedalam bahasa Ternate dikarenakan politik pemerintah HindiaBelanda yang menyebabkan bahasa Belanda hanya dipakai dalam lingkungan yang sangat terbatas, yaitu lingkungan para pegawai negeri, lingkungan elite dan lingkungan istana saja.

Bahasa Cina yang selama berabad-abad menjadi bahasa eksklusif di kalangan masyarakat pedagang Cina di Ternate praktis tidak ada pengaruhnya dalam bahasa Ternate. Demikian pula halnya bahasa Jepang, meskipun secara intensif disebar luaskan keseluruh lapisan masyarakat oleh pemerintah tentara Jepang selama 31/2 tahun, namun jelas tidak pernah populer.

Lepas dari masalah apakah bahasa Ternate termasuk rumpun bahasa Polinesea atau Austronesia, namun selama berabad-abad hingga masa kini bahasa Ternate masih hayat sebagai lingua franca (bahasa-pengantar) di Maluku Utara.Dan bahasa Ternate sebagai bahasa yang hidup yang telah berkembang ratusan tahun, dalam strukturnya ada keistimewaan, yaitu adanya kelamin kata.

Menurut Marx, bahasa pada hakekatnya merupakan suatu sistem simbol yang tidak hanya merupakan urutan-urutan bunyi secara emperis, melaingkan memeliki makna yang sifatnya nonemperis. Dengan demikian bahasa adalah merupakan simbol yang memeliki makna, merupakan alat komunikasi manusia, penuangan emosi manusia serta merupakan sarana pengejawantahan pikiran manusia dalam kehidupan sehari-hari terutama dalam mencari hakikat kebenaran dalam hidupnya. Dengan demikian, Bahasa pada hakekatnya merupakan suatu sistem simbol yang terdiri atas unsur-unsur kata. Maka sebuah kata juga merupakan sebuah simbol, sebab keduanya sama-sama hadir dalam bentuk yang lain.

Dengan demikian bahasa Ternate sebagai sebuah lingua franca (bahasapengantar) di kawasan Nusantara yang dalam strukturnya mengenal kelamin kata.Selain mengenal kelamin kata, bahasa Ternate juga mengenal perasaan kata, seperti halnya bahasa Jawa Kuno dan Jawa Baru. Contoh:Untuk menyebut "aku" 
dalam percakapan sehari-hari dengan orang yang sederajat, cukup mengucapkan ngori. Tapi bila kita berbicara dengan orang yang lebih tua atau dianggap lebih tinggi derajatnya, maka kita harus mengucapkan fangare, sebagai tanda merendahkan diri.Apabila kita berbicara dengan orang yang dianggap sederajat, maka kita menyebut lawan bicara ngona.Yang berarti engkau, kamu. Tapi bila lawan kita lebih tua atau lebih tinggi derajatnya, maka kita menyebutnya iou, sebgai tanda penghormatan.

Semasa pra-Islam bahasa Ternate masih merupakan bahasa liasan, karena diketahui bahasa Ternate tidak mempunyai aksara/huruf sendiri.Baru setelah jaman Islam aksara/huruf Arab-Melayu dipakai untuk menuliskan bahasa Ternate.Bahkan sampai sekarang huruf itu masih terus dipakai.Hanya sayang sekali, bahwa bahasa Ternate tidak dikembangkan melewati pendidikan formil mulai dari pendidikan dasar.Meski demikian, dalam perjalanan sejarah selama berabad-abad hingga masa kini, bahasa Ternate tetap dihayati masyarakat sebagai bahasa praktis dalam pergaulan anatar berbagai suku se Maluku Utara.

\section{B. Bentuk-bentuk Ungkapan Sastra Lisan}

Sastra lisan Ternate kaya dan padat dengan ungkapan-ungkapan simbolis. Menurut L. Rajiloen, pada umumnya mengandung nilai-nilai pendidikan moral yang tradisional, bahkan ada pula yang mengandung nilai-nilai universal. Sebagian dari sastra itu di jadikan syair lagu-lagu daerah yang dinyanyikan untuk mengiringi berbagai tarian adat.Ada pula yang hanya di deklamasikan, baik dalam menolog-monolog, maupun dialog.Misalnya untuk mengiringi lagu dola-bololo (lagu daerah), di deklamasikan oleh para penari dalam monolog.Untuk mengiringi beberapa jenis tarian pergaulan, dola-bololo di deklamasikan dalam dialog.
Penyaluran melalui seni suara dan tarian lebih banyak menarik pendengar dari pada melalui percakapan.Syairnya yang didendengkan di iringi dengan instrumen seperti tifa dan gong yang di ikuti dengan tarian (ronggeng) banyak menarik penggemarnya.Penyajian tersebut di laksanakan menurut perhitungan hari, yaitu lamanya berlangsung sampai sembilan hari sembilan malam, tujuh hari tujuh malam atau kurang dari itu tetapi sebanyak perhitungan hari ganjil.

Bentuk sastra Ternate yang tertua merupakan puisi. Puisinya ada yang merupakan tamsil, pepatah, ibarat, dan peribahasa.Ada pula yang merupakan pantun-pantun bersajak. Biasanya tiap-tiap bait terdiri atas empat baris kalimat, tapi ada juga yang terdiri dari dua baris kalimat. Sajaknya ada yang beraturan, tapi ada pula yang tidak terikat pada sajak, artinya sajk bebas seperti halnya bentuk dan ungkapan puisi modern.

Oleh karena itu di bawah ini saya sajikan contoh-contoh sastra lisan Ternate yang disajikan dalam upacara keagamaan sanjak beraturan maupun yang merupakan sanjak bebas secara singkat dan sederhana.

\section{Dola Bololo}

Dola Bololo atau sepotong ungkapan, pernyataan perasaan dan pendapat seseorang, dalam bentuk sindirian dan tamsilan.Merupakan ciri kebijakan seseorang dalam masyarakat untuk menyampaikan perasaan dan pendapatnya melalui peribahasa kepada seseorang atau temannya, agar temannya tidak merasa tersingung karena ketentuan budayanya.Berkomunikasi berbahasa mengunakan dola bololo lebih berkesan di mana saja tempat dan waktu bila bertemu. Contoh kalimat.

Fala to mataka-taka

Dego-dego to ruraka

Artinnya:

Rumah yang aku tidak biasa memasukinya

Malu menduduki kursinya. 


\section{0 | JURNAL ILMU BUDAYA}

Volume 6, Nomor 1, Juni 2018

\section{Dalil Moro}

Dalil Moro ialah bentuk puisi sastra lama yang dalam pribahasannya mengungkapkan perumpamaan berbentuk dalil sebagai contoh untuk ditiru, merupakan warisan nenek moyang. Isi dan pengertian syairnya memuat hakikat kehidupan manusia, bahwa setiap individu atau masyarakat di tuntut dapat menempatkan dirinya dalam masyarakat serta mampu menciptakan suasana keragaman yang dapat menjalin ikatan antara sesama manusia dalam hubungan kekeluargaan sampai ke dalam kelompok yang besar (masyarakat). Tapi jangan terbawa oleh situasi yang mengiring kearah yang tak menentu atau terombang ambing oleh keadaanya.

Penyampaiannya

melalui percakapan, terutama kalangan orang tua, dalam bentuk nyayian yang di dendangkan oleh seorang biduan. Waktu dan tempat tergantung pada penyair itu sendiri.

Contoh kalimat:

Lule-lule katomahale

Sibubu besa siwohe wange

Nage mapahala laho

Pirara ena dadi kajoro

Artinya

Berguling-guling ditanah

Mandi kehujanan kepanasan

Siapa yang melakukan kebaikan

Maka tanaman itu akan terpelihara

\section{Dalil Tifa}

Sebagaimana Dalil Moro, Dalil Tifa juga berbentuk pribahasa, pernyataan pendapat yang bersifat petunjuk dan nasehat yang di ungkapkan dalam bentuk dalil. Isi yang terkandung di dalamnya kebanyakan bernafaskan dalil bersifat keagamaan.Pengertiannya di identikan dengan tifa (beduk) tujuannya mengingatkan orang menaaati perintah pangilan agama.

Dalil Tifa di gemari oleh orang tua.Dalam percakapan selalu di pergunakan dalil tifa itu, karena mempersoalkan masalah kejadian manusia, datangnya maut, dan kehidupan di alam nanti.Kebanyakan di sampaikan orang tua pada waktu mereka bertemu. Dalil tifa ini juga dapat didendangkan oleh biduan yang mahir melakukannya.

Contoh kalimat.

Tagi ngoko liba-liba

Bajalan jao gudu kawasa

Gudu moju si fosusa

Seba se fowaje koa

Artinya

Kita jalan pada jalan yang berliku

Berjalan jauh terlampau jauh

Saking jauhnya makin susah

Kalau sudah dekat mau bilang apa

\section{Mantra}

Mantra sebagai bagian dari pelengkap budaya daerah mempunyai fungsi dan peran penting dalam masyarakat pada masa lampau maupun masa kini, dan dapat dijumpai di mana-mana mantra itu di seluruh tanah air. Dalam budaya masyarakat Ternate pengunaan dan tujuannya sama yakni mantra berfungsi untuk pengobatan, kekebalan dengan tujuan membela diri dari perkelahian ataupun peperangan agar di kasihi orang, memohon pertolongan dari roh gaib, mengucapkan syukur pada ruh gaib atau menolak bencana dan sebagainnya. Dengan kata lain mantra sebagai sastra lisan sangat berfungsi dalam kehidupan masyarakat pada masa lalu maupun masa kini.

Menurut L. Rajiloen , mantra di gunakan untuk memohon bantuan ruh gaib ataupun jin untuk melindungi warga masyarkat yang bersangkutan dari bahaya serangan penyakit ataupun meminta pertolongan penyembuhan atas warga yang di timpa penyakit. Dengan membaca mantra memohon kehadiran ruh gaib atau jin, di susul dengan bunyi tifa dan gong serta syair bersifat mantra, dikuti dengan tarian oleh orang tertentu.

Contoh kalimat.

To oro ri salawaku 


\section{1 | JURNAL ILMU BUDAYA}

Volume 6, Nomor 1, Juni 2018

To ori ri sagu-sagu

Doka ge lulu polote

Makaha mai I robo

Matufa mai lenge

Mamancia mai soro

Artinya

$\mathrm{Ku}$ ambil perisaiku

$\mathrm{Ku}$ ambil tombakku

Seperti gunung meletus

Tanah pun retak

Langit pun miring

Musuh pun lari

\section{Tamsil}

Sebagaimana dalam kesusatraan Indonesia, tamsil dalam sastra lisan Ternate berisi nasehat dan petunjuk agama.Sebagai peringatan kepada pemeluknya agar benar-benar mempelajari ilmu agama dan mengamalkan dalam kehidupannya. Penyajian tamsil di lakukan oleh pemuka agama pada acara berkabung hari kematian di rumah tempat acara berkabung itu di lakukan.

Tujuannya supaya pendengar yang hadir dalam acara berkabung turut mengenang bahwa mereka pun akan melalui jalan sebagaimana si mati yang telah mendahului mereka itu. Kematian itu dating menjenguk seseorang tanpa ada pemberitahuan terlebih dahulu, maka dari itu selagi masi ada kesempatan (hidup), kita perlu menelusuri dan menuntut tuntutan yang diwajibkan oleh agama.

Contoh kalimat

Hai sagala ngone ronga ragibin

Lo bolo ri nongoru fo ma moi-moi

Tego la fosusunyinga $\mathrm{La}$ fosigiha nyinga

Himo-himo nga wowasu se nga dodoto Artinya

Hai segala umat manusia

Kakak adik kita semua

Duduk kita kenang dan simpan di hati

Pesan dan ajaran orang tua

\section{Rorasa ( Babaso )}

Rorasa, bentuk sastra lisan, berfungsi dalam tata kehidupan masyarakat.Syairnya berbentuk pernyataan perasaan nasihat serta petunjuk. Penyajiannya pada seremonial tertentu, terutama dalam upacara adat, seperti pelantikan Sultan, persembahan upeti kepada Sultan, menerima tamu agung, upacara perkawinan, jamuan makan adat, upaya penguburan Sultan, dan upaya adat lain. Rorasa merupakan, prakata pada upaca adat.Penyajiannya, harus disampaikan oleh pemuka adat atau agama.

Contoh kalimat:

Guru-guru se haji-haji se ulama-ulama

Makaramat se maaulia nga barakat se mustajab

Madarajat se mujijat se mahaibat

Se mahluk malulahi

Artinnya

Para guru, haji dan ulama memeliki kharamah

Para Auliyah mempunyai berkah, mujijat dan tempat yang mustajab

Bagi siapa yang memohon pertolongan Maka permintaannya akan di sampaikan

\section{Upacara ritual Salai Jin (upacara jin)}

Upacara ritual Salai Jin (upacara jin)di KepulauanTernate merupakan budaya yang telah diwariskan turuntemurun dan keberadaanya telah melewati kurun waktu yangcukup panjang berabad-abad lamanya. Sebagai suatu kebudayaan, sebagaimanakebudayaankebudayaan lainnya di tanah air kita ini, begitu pulaupacara ritual SalaiJin yang ternyata tidak hanya memiliki kerangkaaktivitas berupa upacara dan ritus sebagai sistem sosial, akan tetapi juga memilikikerangka gagasan dan konsep pikiran sebagai inti dari suatu sistembudaya serta memiliki kebudayaan fisik sebagai produk dari perilaku-perilaku manusia yang terjalin secara konsentri. 


\section{2 | JURNAL ILMU BUDAYA}

Volume 6, Nomor 1, Juni 2018

Upacara Jin/roh halus oleh komunitaskomunitas tertentu di Kepulauan Ternate hingga kini masih dipelihara dan dipertahankan sebagai sahabat dan dapat dipergunakan pada saat-saat tertentu, yaitu bila mereka berada pada kondisi yang kritis, seperti sakit yang bertahun-tahun, masyarakat dan kampung yang diserang wabah, atau bila mereka berhadapan dengan musuh (peperangan).

Persahabatan atau hubungan yang harmonis si pemelihara dan jin piaraannya didasarkan atas saling membutuhkan, bila jin telah memenuhi hajat mereka, maka mereka pun harus memenuhi kebutuhan jin yang masih memiliki sifat-sifat manusiawi tersebut, dengan cara menyediakan Dimai serta melaksanakan upacara Salai Jin yang ritual sifatnya.

Penyelenggaraan upacara Salai Jin bermotif penyembahan dan pemujaan terhadap makhluk halus.Wujud dari pemujaan atau penyembahan ini adalah dalam bentuk upacara, maka pelaksanaannya memiliki urutanurutan secara sistematis yang tidak boleh dilampaui.Di dalam upacara ini disajikan sesajian dan tarian-tarian yang dimainkan oleh kelompok salai yang terdiri dari pria dan wanita dewasa atau orang tua, mereka merupakan keluarga yang memiliki hubungan garis keturunan dan tarian tersebut diiringi oleh suara Tifa (gendang) serta Rababu (biola) dan sesekali diikuti oleh irama dendang seperti moro-moro, kabuta, daki, denge-denge dan pandara yang berlangsung pada suatu tempat (ruangan/sabua) yang didekorasi sedemikian rupa sesuai dengan ketentuannya.

Sebagaimana ungkapan dalam bahasa Ternate yaitu "Ngone manusia I yaya jin, ma papa Nabi, toma you ine ngone se Nur, Re toma alu ongom ende ngofa sedano Jadi ngontia jin ngom ya yaya,yaya yang para" Artinya "Kita manusia ini punya Ibu Jin dan punya Bapak Nabi pada tingkatan atas kita ini adalah cahaya dan pada tingkatan bawah, kita ini adalah anak cucunya, maka kami tidak bisa tinggalkan karena Jin adalah Ibu kami, yakni Ibu yang memelihara kami.

Keberadaan uparaca salai jin selalu di hubungkan dengan mitos bahwa Salai Jin atau tarian jin ini adalah ungkapan rasa terima kasih kepada jin dan sebagai ekspresi rasa semangat ibarat Ibu dari keempat Raja Kie Raha ini mengayun bayi dalam buayan (buwebuwe), selanjutnya mereka hubungkan juga dengan 7 putri khayangan itu yang bapaknya berasal dari Jin, yakni salah seorang dari 7 putri khayangan itu sempat disunting oleh manusia bumi yang bernama Djafar Noh dan melahirkan empat orang anak yang kemudian menjadi Raja Kie Raha ini dan beranak cucu sehingga saat ini.

\section{Kepercayaan dan Ritual Keagamaan}

Dari perspektif sejarah, masyarakat Ternate Maluku Utara, dahulunya menganut aliran kepercayaan dinamisme di samping kepercayaan Animisme.Di antara wujud kepercayaan dinamisme adalah melalui pemujaan terhadap gunung.Bahkan aktivitas tersebut hingga saat itu masih dilakukan oleh sebagian kalangan dengan tetap pada sistem kepercayaan sebagai salah satu sumber kekuatan gaib (supranatural) yang dapat dimintai pertolongannya untuk memberikan keselamatan dan kesejahteraan hidup.

Kepercayaan lama itu sedemikian mendarah-daging dalam kehidupan masyarakat sehingga setelah mereka memeluk agama Islam, mereka masih setia kepada tradisi leluhur mereka. Para Sultan (sesudah jaman Islam) setelah dinobatkan, wajib untuk melakukan upacara kololi kiye dan fere kiyemutubu. Hanya saja doa kie tidak lagi ditunjukan kepada kekuatan gaib gunung berapi melainkan ke Hidayat Allah SWT. Bahkan ada sebagian para calon haji yang hendak menunaikan haji ke tanah 
suci, selalu setiap melakukan upacara Kololi Kiye dan Fere Kiye Matubu.

Pemujaan terhadap gunung berapi itu selain dilakukan dengan sajian dan doa permohonan pertolongan, juga dengan cara memberikan penghormatan. Setiap yang mempunyai sesuatu hajat, misalnya hendak merantau, berperang, mendirikan rumah, panenan rempah-rempah, hendak melangsungkan pernikahan, mereka berjalan mengelilingi gunung sampai ke puncak. Upacara penghormatan, pemujaan dengan jalan mengelilingi gunung disebut "Kololi Kie" sedangkan upacara mendaki puncak gunung disebut "Fere Kiye Matubu”.

Selain kepercayaan tersebut terdapat juga kepercayaan lainya yang masih dipegang oleh sebagian warga adalah tradisi Wonge. Secara semantik Wonge memiliki kandungan makna memberikan semacam tempat berkumpul untuk para arwah nenek-moyang yang letaknya di atas wuwungan dekat pintu dalam rumah.Tempat arwah leluhur yang asli itu disebut "arca".Tempat itu dilengkapi sesajian berupa nasi kuning, siri-pinang, tembakau atau rokok, tuak dan secara berkala diasapi dengan bakaran dupa kemenyan.

Wonge adalah suatu wujud animisme yang tersebar luas bukan saja di Maluku Utara, akan tetapi juga sudah merupakan kepercayaan asli jaman pra-Islam di pulaupulau Piliphina Selatan, Sulawesi Utara, Sulawesi Tengah, pantai-pantai SulawesiTengah Selatan, Kepulauan Sula bahkan sampai di pulau-pulau sekitar Papua. Selain itu juga merupakan salah satu wujud animisme secara fisik berbentuk arca/kayu lelaki-perempuan untuk gambaran (visualisasi) nenekmoyang.Ditempatkan di dalam rumahrumahan yang diberi sesajian. Oleh karena itulah rumah-rumahan diberi sesajian, berisi arca-arca nenek-moyang yang disebut fala wonge (fala-rumah, wonge $=$ arca).

\section{Kesimpulan}

Sebagaimana kesusatraan di Indonesia yang beragam bentuk dan jenisnya.Begitu pula dalam sastra lisan Ternate di jumpai bentuk dan jenis yang beraneka.Apabila di kaji lebih jauh dan mendalam, bentuk dan jenis serta isi syair dapat diberi penggolongan menurut kurun waktu yaitu periode sebelum masuknya agama Islam dan sesudahnya. Selain memeliki bentuk puisi yang kaya, sastra Ternate juga memeliki bentuk prosa yang berupa karirkarir ataupun cita-cita rakyat yang legendaris. Bentuk prosa itu pun merupakan sastra lisan yang pemeliharaanya di lakukan secara tradisional dengan leluri (overlevering).Sekitar abad ke XII, setelah masyarkat Ternate mengenal akasara/huruf Arab, ada usaha untuk merekam kesusatraanya dengan mempergunakan huruf Arab-Melayu.Naskah-naskah sastra tertulis berhurup Arab- Melayu itu merupakan tulisan tangan (handschrift) diatas sejenis kertas yang terbuat dari kayu tomboku.

Dari contoh bentuk prosa yang merupakan nukilan dari tulisan sejarah atau pun kronik kesultanan Ternate itu, kita dapat mengetahui bahwa sastra yang berbentuk prosa banyak di pengaruhi bahasa-bahasa Melayu Arab, bahkan juga bahasa-bahasa asing. Namun kita juga melihat ciri krakteristik bahwa istilahistilah kata-kata yang berasal dari non Ternate diserap dengan mengejakannya ke dalam lafal bahasa Ternate.Misalnya meneer menjadi mener,mayor menjadi majoru, kapitein menjadi kapita, dan soldaat menjadi solodadu. Bahkan namanama orang asing seperti nama residen kolonial Belanda, komendan garnezum yaitu, Dirk Frederik Hermanus Helbach dan Le brom di ubah menjadi Derek Federek Hermanus Helbak dan lebrom.

Sastra Ternate sebenarnya merupakan semacam prosa liris yang harus di baca dengan bahasa berirama.Dan terbagi atas semacam bait-bait yang mengingatkan 


\section{4 | JURNAL ILMU BUDAYA}

Volume 6, Nomor 1, Juni 2018

kepada pupuh dalam penulisan sejarah kronik di Jawa yang literer.Masih ada bentuk prosa liris yang berupa sastra lisan lainnya yaitu suba atau laporan kenegaraan yang di ucapkan oleh jugugu (perdana menteri) kepada sultan dan rorasa yang di ucapkan sesudah upacara joko kaha (menginjak tanah) dalam menyambut tamu-tamu agung.

Namun hingga kini sastra Ternate belum tergali dan tersusun dalam bentuk diskripsi yang baik hingga di khawatirkan lambat-laun akan punah khasanah sastra Ternate akibat pengaruh perkembangan kebudayaan nasional dengan proses waktu yang terus berjalan. Generasi muda sebagai pewaris hanya sebagian kecil saja yang mau memelikinya.Itu pun yang dimiliki hanya bentuk dan jenis yang disenanginya saja. Pada hal jika di teliti lebih mendalam sastra lisan akan menghasilkan peran yang berguna dalam membina dan mengembangkan kesusastraan nasional, yang di petik dari hasilnya baik dalam bentuk puisi, prosa lirik, maupun prosa. Dengan demikian, menurut Ernst Cassirer, kebudayaan sebagai olahan dari rasa, cipta dan karsa umat manusia, tidak hanya sekedar memenuhi kebutuhan fisik lahiriah semata, tetapi juga membentuk dan menumbuhkan rasa percaya diri kemauan dan kemampuan para pelaku kebudayaan itu. Sebagaimana Koentjaraningrat menjelaskan bahwa nilainilai kebudayaan itu dapat membantu kita dalam hal mengembangkan sifat-sifat mental menghidupkan pembangunan suatu bangsa. Hal senada juga di kemukakan oleh mantan presiden Soeharto bahwa bangsa yang kehilangan kebudayaanya akan kehilangan kepribadiaanya. Dan bangsa yang kehilangan kepribadian akan menjadi bangsa yang terombang ambing di antara bangsa yang lain.

\section{Daftar Pustaka}

Abdul Hamid Hasan, Aroma Sejarah dan Budaya Temate, Jakarta: Centra Pustaka Utama, 1999.

\section{Adnan Amal, Kepulauan Rempah-} Rempah: Perjalanan Sejarah Maluku Utara 1250 - 1950. Jakarta: Gora Pustaka Indonesia, 2007.

Ernst Cassirer, Manusia dan Kebudayaan: sebuah Esei Tentang Manusia. Jakarta: Gramedia, 1987.

E.K. M. Masinambaw "Halmahera dan Raja Ampat Konsep dan Strategi Penelitian, Jakarta: LEKNAS-LIPI, 1980.

Gorys Keraf, Diksi dan Gaya Bahasa, Jakarta, Gramedia, 2007.

Harimurti Kridalaksana, Pembentukan Kata dalam Bahasa Indonesia, Jakarta, Gramedia, 2007.

Hasmawati dan Rustam Hasim “ Kedudukan Elite Kesultanan Dalam Masyarakat Ternate" Jurnal Ilmu Budaya: Volume 5 No 2 Desember 2017. Universitas Hasanudin Makasar.

Jusuf Abdulrahman, Kesultanan Temate Dalam Jou Ngon Ka Dada Madopo Fangare Ngona Ka Alam Madiki, Manado: Media Pustaka, 2002. et al, Temate Bandar Jalur Sutra, Jakarta:LITS, 2001.

Koentjaraningrat.Perespsi Tentang Kebudayaan. Press 1990

L. Rajiloen, Sejarah Kebudayaan Maluku Utara, Ternate: Depdikbud, 1980.

, Daratan Tinggi Foramadiahi adalah Temate Awal ke Dataran Rendah Limau Jore-Jore Sebagai Temate Akhir. Jakarta: Depdikbud, 1982.

, Uli Siwa-Uli Lima Melatar Belakangi Peristiwa Sejarah Kejuangan Para Kolano/Sultan Maloko Kiye Raha MalukuUtara,Ternate: Departemen P\&K, 1983. 


\section{5 | JURNAL ILMU BUDAYA}

Volume 6, Nomor 1, Juni 2018

Luhulima, C.P.F. (Ed.), Bunga Rampai Seiarah Maluku, Jakarta: LIPl, 1971.

R.Z. Leirissa, et. al., Ternate Sebagai Bandar Jalur Sutra, Jakarta: Proyek Inventarisasi dan Dokumentasi Sejarah Nasional

Diroktorat Sejarah dan Nilai Nasional, Depdikbud, Rl, 1999.

Rustam Hasim " Dari Mitos Tujuh Putri hingga Legitimasi Agama: Sumber Kekuasaan Sultan Ternate. Jurnal Sasdaya, Volume 1, N0.2, Mei 2017. Universitas Gadjah Mada. 